\title{
Helicobacter pylori cag pathogenicity island genes: clinical relevance for peptic ulcer disease development in Brazil
}

\author{
Rejane Mattar, Sergio Barbosa Marques, Maria do Socorro Monteiro, \\ Anibal Ferreira dos Santos, Kiyoshi Iriya and Flair José Carrilho \\ Department of Gastroenterology, University of São Paulo School of Medicine, São Paulo, SP, \\ Brazil
}

Correspondence

Rejane Mattar

rmattar@hcnet.usp.bror

rejane-mattar@ig.com.br

Received 7 July 2006

Accepted 28 August 2006

\begin{abstract}
The purpose of this study was to verify whether the presence of any of the Helicobacter pylori cagPAI genes or segments - $\operatorname{cag} A, \operatorname{cag} A$ promoter, $\operatorname{cag} E, \operatorname{cag} M, \operatorname{tnp} B, \operatorname{tnp} A, \operatorname{cag} T$ and the left end of the cag II (LEC) region - would be a useful marker for the risk of peptic ulcer disease development. H. pylori DNA extracted from positive urease tests of 150 peptic ulcer patients and 65 dyspeptic controls was analysed by PCR. Duodenal ulcers were present in 110, gastric ulcers in 23 and both gastric and duodenal ulcers in 17 patients. A significant association $(P<0.001)$ was found between a conserved cagPAl and peptic ulcer disease (34\%). The positivity of the $\operatorname{cag} A$ gene varied according to the region of the gene that was amplified. The region near to the promoter was present in almost all of the H. pylori isolates (97.2\%). The segment from nt 1764 to 2083 and the extreme right end were frequently deleted in the isolates from the controls $(P<0.01)$. The positivity of the promoter region of $\operatorname{cag} A$ and $\operatorname{cag} T$, cagE, cagM and LEC showed a significant difference between the isolates from peptic ulcer patients and from the controls $(P<0.01)$. Patients usually had moderate gastritis; however, the intensity of the active inflammation was higher in the peptic ulcer group $(P<0.001)$. cagT, cagM, LEC and the right end terminus of the cagA-positive $H$. pylori isolates were associated with a 27-fold, 8-fold, 4-fold and 4-fold risk of peptic ulcer disease, respectively, and may be useful markers to identify individuals at higher risk of peptic ulcer disease development in Brazil.
\end{abstract}

\section{INTRODUCTION}

Helicobacter pylori colonizes the human stomach causing chronic gastritis. A small number of individuals progress to peptic ulcer or gastric cancer. Multiple bacterial and/or host factors are involved in disease development (Backert et al., 2004; Peek, 2005).

H. pylori clinical isolates are classified into two types according to their degree of pathogenicity. Type I, associated with severe disease pathology, expresses functional VacA (vacuolating cytotoxin A) and contains an insertion of $40 \mathrm{~kb}$ of foreign DNA, the cag (cytotoxin-associated gene) pathogenicity island (cagPAI). Type II lacks cagPAI, harbours a non-toxic form of VacA and is regarded as less virulent (Censini et al., 1996; Backert et al., 2004).

The cagPAI may be divided into two regions, cag I and cag II, by a novel insertion sequence (IS605). There are

Abbreviations: Apcag, cagA promoter region; cagPAl, cag pathogenicity island; IL, interleukin; LEC, left end of the cag II. approximately 16 and 15 open reading frames in cag I and cag II, respectively (Censini et al., 1996; Akopyants et al., 1998). The cagPAI encodes a type IV secretion system, which delivers CagA into the cytosol of gastric epithelial cells (Covacci \& Rappuoli, 2000) through a rigid needle structure covered by Cag7 or CagY, a VirB10-homologous protein, and CagT, a VirB7-homologous protein, at the base (Rohde et al., 2003). CagA is tyrosine-phosphorylated by Src-family kinases (Selbach et al., 2002), triggering the elongated hummingbird phenotype (Higashi et al., 2005) similar to that of hepatocyte growth factor (Segal et al., 1999). Numerous phosphorylation motifs in the cagA gene have been identified by specific PCR assays (Owen et al., 2003; Zhang et al., 2005).

Type I isolates also mediate interleukin 8 (IL-8) secretion from gastric epithelial cells by NF- $\kappa \mathrm{B}$ activation (Segal et al., 1997; Glocker et al., 1998; Maeda et al., 2001). cagE (Tummuru et al., 1995; Maeda et al., 2001), cagG (Hsu et al., 2002), cagH, cagI, cagL and cagM are necessary for NF- $\kappa \mathrm{B}$ activation; however, $\operatorname{cag} A, \operatorname{cag} N, \operatorname{cag} P$ and the left end of the cag II region (LEC) are not required (Segal et al., 1997; Glocker et al., 1998; Fischer et al., 2001). 
In Brazil, the prevalence of $H$. pylori in the normal population is high (78.8\%) (Fujioka et al., 2001). Characterization of a marker to identify patients who are at higher risk of peptic ulcer disease development would be useful for clinical practice, as $H$. pylori genotyping from positive urease tests is easily performed in the laboratory.

\section{METHODS}

Patients. H. pylori DNA extracted from positive urease tests of 150 peptic ulcer patients and 65 non-ulcer dyspeptic controls, designated by numbers and letters, was used in this study. Controls were randomly selected from 500 consecutive endoscopies. Sixty-one were women $(93.8 \%)$ and four $(6.2 \%)$ were men, the sex ratio being $15: 1$, with a mean age of 38.7 years. In the peptic ulcer group, 92 were women $(61.3 \%)$ and 58 were men $(38.7 \%)$, the sex ratio being $1.6: 1$, with a mean age of 46.8 years. Duodenal ulcers were present in 110, gastric ulcers in 23 and both gastric and duodenal ulcers in 17 patients. These patients had first presentation of the illness and came for diagnosis by upper digestive tract endoscopy. Thus, none of the subjects enrolled had previously taken medications, such as anti-secretory drugs or anti-microbial agents for $H$. pylori eradication, or were receiving non-steroidal anti-inflammatory drugs. This study was approved by the local ethics committee and patients gave written informed consent. Biopsies taken from the antrum and the corpus of the stomach were scored according to the updated Sydney system classification and grading of gastritis (Dixon et al., 1996).

H. pylori genotyping. DNA extraction from gastric biopsies of positive in-house urease tests from the antrum by a salting out procedure and PCR were performed according to previously reported techniques (Mattar et al., 2005). The PCR primers are listed in Table 1. Amplification was performed under the following conditions for cagA2 (Covacci et al., 1993): initial denaturation at $94{ }^{\circ} \mathrm{C}$ for $5 \mathrm{~min}$, followed by 27 cycles of denaturation at $94{ }^{\circ} \mathrm{C}$ for $30 \mathrm{~s}$, annealing at $53{ }^{\circ} \mathrm{C}$ for $30 \mathrm{~s}$ and extension at $72{ }^{\circ} \mathrm{C}$ for $30 \mathrm{~s}$. PCRs of cagM, tnpB (Kidd et al., 2001), cagA1 and cagA3 (Ikenoue et al., 2001) were performed using 40 cycles with an annealing temperature of $52^{\circ} \mathrm{C}$. PCRs of $\operatorname{tnp} A$ (Kidd et al., 2001), cagT, cagE, the cagA promoter (Apcag) (Ikenoue et al., 2001) and LEC (Akopyants et al., 1998) were performed using 40 cycles with an annealing temperature of $55^{\circ} \mathrm{C}$. The final extension at $72{ }^{\circ} \mathrm{C}$ was for $10 \mathrm{~min}$. A set of primers (P1 and $\mathrm{P} 2$ ) that amplified a $26 \mathrm{kDa}$ antigen $(\mathrm{Ag})$ gene present in all strains of $H$. pylori (Hammar et al., 1992) was used as a positive PCR control under the following conditions: initial denaturation at $94{ }^{\circ} \mathrm{C}$ for $5 \mathrm{~min}$, followed by 40 cycles of denaturation at $93^{\circ} \mathrm{C}$ for $1 \mathrm{~min}$, annealing at $57^{\circ} \mathrm{C}$ for $2 \mathrm{~min}$ and extension at $70^{\circ} \mathrm{C}$ for $2 \mathrm{~min}$. Analysis of PCR products was performed by electrophoresis on $2 \%$ agarose gel, followed by staining with ethidium bromide.

Statistical analysis. Statistical analysis was performed using $\chi^{2}$ and Fisher's exact tests, using SPSS. A value of $P<0.05$ was considered statistically significant. Significant factors were subjected to multivariate stepwise logistic regression analysis.

\section{RESULTS AND DISCUSSION}

\section{Amplification of cagPAl genes}

PCRs yielded high-quality products with the expected sizes and reproducible results (Fig. 1); negative PCRs were repeated for confirmation, along with positive controls.

Table 1. Primers used for $H$. pylori genotyping

\begin{tabular}{|c|c|c|c|c|c|}
\hline Region & Primer & Primer sequence $\left(5^{\prime} \rightarrow 3^{\prime}\right)$ & Product size (bp) & Location (nt) & GenBank accession no. \\
\hline \multirow[t]{2}{*}{$\operatorname{cag} M$} & Cag5 & ACAAATACAAAAAAGAAAAAGAGGC & 586 & $8022-8046$ & U60176 \\
\hline & Cag6 & ATTTTTCAACAAGTTAGAAAAAGCC & & $8608-8584$ & U60176 \\
\hline \multirow[t]{2}{*}{$\operatorname{tnp} A$} & Cag10 & ATCAGTCCAAAAAGTTTTTTCTTTCC & 344 & $4280-4305$ & U60176 \\
\hline & Cag11 & TAAGGGGGTATATTTCAACCAACCG & & $4614-4590$ & U60176 \\
\hline \multirow[t]{2}{*}{$\operatorname{tnp} B$} & Cag8 & CGCTCTCССТAAATTCAAAGAGGGC & 569 & $5080-5104$ & U60176 \\
\hline & Cag9 & AGCTAGGGAAAAATCTGTCTATGCC & & $5657-5633$ & U60176 \\
\hline \multirow[t]{2}{*}{$\operatorname{cag} E$} & CagE-F1 & GCGATTGTTATTGTGCTTGTAG & 329 & $16891-16870$ & U60176 \\
\hline & CagE-R1 & GAAGTGGTTAAAAAATCAATGCCCC & & $16563-16587$ & U60176 \\
\hline \multirow[t]{2}{*}{$\operatorname{cag} T$} & CagT-F1 & CCATGTTTATACGCCTGTGT & 301 & $442-461$ & U60176 \\
\hline & CagT-R1 & CATCACCACACССТTTTGAT & & $723-742$ & U60176 \\
\hline \multirow[t]{2}{*}{$\operatorname{cagA3}$} & CagA-F1 & AACAGGACAAGTAGCTAGCC & 701 & $2700-2719$ & AF001357 \\
\hline & CagA-R1 & TATTAATGCGTGTGTGGCTG & & $3400-3381$ & AF001357 \\
\hline \multirow[t]{2}{*}{$\operatorname{cagA2}$} & CAG-1 & AGACAACTTGAGCGAGAAAG & 320 & $1764-1783$ & X70039 \\
\hline & CAG-2 & TATTGGGATTCTTGGAGGCG & & $2064-2083$ & X70039 \\
\hline \multirow[t]{2}{*}{$\operatorname{cagA1}$} & CagA-F2 & GATAACAGGCAAGCTTTTGA & 349 & $157-176$ & AF001357 \\
\hline & CagA-R2 & CTGCAAAAGATTGTTTGGCAGA & & $505-484$ & AF001357 \\
\hline \multirow[t]{2}{*}{ Apcag } & CagA-R2 & CTGCAAAAGATTGTTTGGCAGA & 730 & $505-484$ & AF001357 \\
\hline & AP-F1 & GTGGGTAAAAATGTGAATCG & & $18738-18757$ & U60176 \\
\hline \multirow[t]{2}{*}{ LEC } & LEC-F1 & ACATTTTGGCTAAATAAACGCTG & $320-550$ & $3920-3942$ & AC000108 \\
\hline & LEC-R1 & TCTCCATGTTGCCATTATGCT & & $4303-4283$ & AC000108 \\
\hline \multirow[t]{2}{*}{$\operatorname{Ag}^{*}$} & P1 & TGGCGTGTCTATTGACAGCGAGC & 298 & $220-242$ & M55507 \\
\hline & $\mathrm{P} 2$ & CGTGCTGGGCATACTTCACCATG & & $500-522$ & M55507 \\
\hline
\end{tabular}

${ }^{\star} \mathrm{Ag}$, DNA sequence of a species-specific protein antigen of $26 \mathrm{kDa}$ present in all strains of $H$. pylori. 


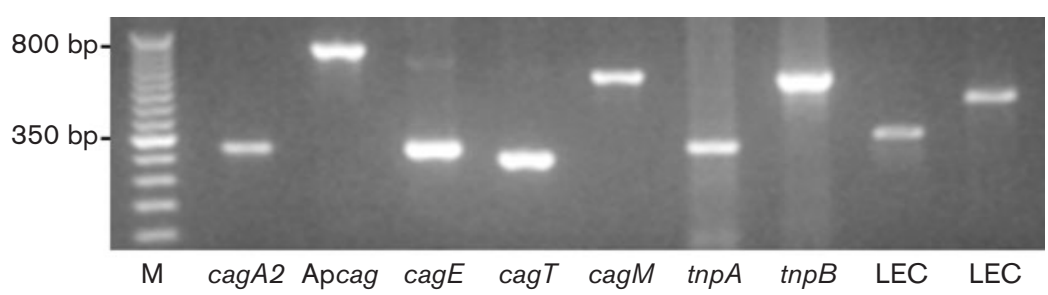

Fig. 1. Agarose gel electrophoresis of the cagPAl gene PCR products: cagA2 (320 bp), Apcag (730 bp), cagE (329 bp), cagT (301 bp), сagM (586 bp), tnpA (344 bp) from case 45A; tnpB (569 bp) from case $39 \mathrm{~A}$; LEC (350 bp) from case 45A; and LEC (500 bp) from case 46A. M, $50 \mathrm{bp}$ DNA ladder (Invitrogen) comprising fragments from 50 to $800 \mathrm{bp}$.
The PCR product size of the LEC varied in length from 320 to $550 \mathrm{bp}$, due to insertions or deletions just within the left end of the cag gene (Akopyants et al., 1998). Most of the studied isolates had a partially deleted cagPAI; no $H$. pylori isolate had a totally deleted cagPAI.

The profile of $H$. pylori cagPAI genes shows great variability worldwide. Fifty per cent of strains from West India are devoid of the entire island of genes (Kauser et al., 2004), $32 \%$ in France (Audibert et al., 2001), 9 \% in Sweden (Nilsson et al., 2003) and the USA (Hsu et al., 2002) and $1 \%$ in Japan (Ikenoue et al., 2001). In the present report, none of the strains showed complete deletion of the cagPAI genes. Total deletion of cagPAI has been associated with lower production of IL-8 in vitro (Audibert et al., 2001; Hsu et al., 2002). However, association of the presence of any gene of the cagPAI or the intactness of the cagPAI with clinical outcome had been contradictory; some reports have shown an association (Jenks et al., 1998; Ikenoue et al., 2001; Kidd et al., 2001; Nilsson et al., 2003), whilst others have not (Hsu et al., 2002).

\section{cagPAl gene positivity and risk of peptic ulcer disease}

Fifty-three $(24.7 \%)$ of the $H$. pylori isolates studied were positive for all of the cagPAI genes: two isolates $(3 \%)$ from the controls and $51(34 \%)$ from the peptic ulcer group. The number of peptic ulcer strains $(34 \%)$ positive for the entire set of cagPAI genes was low in comparison with that in other countries, such as the USA ( $88 \%$; Hsu et al., 2002), Japan (100\%; Ikenoue et al., 2001) and South Africa (78\%; Kidd et al., 2001). The higher frequency of deletions in the cagPAI of Brazilian peptic ulcer $H$. pylori isolates could be a geographical trait. However, the presence of these genes overall had a significant association with peptic ulcers $(P$ $<0.001$ ), although this was not an independent risk factor for peptic ulcer disease (see Table 4) and there was no significant association with intensity of gastritis (see Table 6). Conversely, colonization with intact cagPAI-type strains has been associated with a fivefold increased risk for diagnosis of duodenal ulcers or gastric cancer (Nilsson et al., 2003).

The cagA gene has been considered to be a marker of the presence of the cagPAI (Censini et al., 1996) and has been associated with peptic ulcer disease (Rudi et al., 1998). Thus, three different segments of the cagA gene were analysed, nt 157-505 (cagA1), nt 1764-2083 (cagA2) and nt 2700-3400 (cagA3). The positivity of the cagA gene depended on the region of the gene under evaluation, as shown in Table 2. The segment close to the promoter was present in almost all of the $H$. pylori isolates, from peptic ulcer $(96.7 \%)$ and controls $(98.5 \%)$. However, the segment in the middle of the cagA gene (cagA2) and the right end terminus (cagA3) were not detected in the majority of the isolates from the controls in relation to the peptic ulcer isolates $(P<0.01)$. Kauser et al. (2004) reported that the extreme right end of the cagA gene was frequently found to be rearranged in all African isolates compared with those from other countries, although the proximal portion of this gene was present in $100 \%$ of the African isolates. Interestingly, Brazilians are a mixture of races with an important contribution from

Table 2. Positivity of cagPAl genes in $H$. pylori isolates from patients with peptic ulcers and from control patients

\begin{tabular}{|c|c|c|c|c|}
\hline Gene & No. of peptic ulcer patients (\%) & No. of controls (\%) & Total no. (\%) & $P$ value \\
\hline $\operatorname{cag} T$ & $147(98)$ & $38(58.5)$ & $185(86)$ & $<0.01$ \\
\hline $\operatorname{tnp} B$ & $24(16)$ & $5(7.7)$ & $29(13.5)$ & \\
\hline $\operatorname{cag} M$ & $117(78)$ & $16(24.6)$ & $133(61.9)$ & $<0.01$ \\
\hline $\operatorname{cag} E$ & $144(96)$ & $48(73.8)$ & $192(89.3)$ & $<0.01$ \\
\hline $\operatorname{cag} A 1$ & $145(96.7)$ & $64(98.5)$ & $209(97.2)$ & \\
\hline $\operatorname{cag} A 2$ & $113(75.3)$ & $17(26.2)$ & $130(60.5)$ & $<0.01$ \\
\hline $\operatorname{cag} A 3$ & $78(52)$ & $18(27.7)$ & $96(44.7)$ & $<0.01$ \\
\hline Total & 150 & 65 & 215 & \\
\hline
\end{tabular}


Table 3. Relationship between independent factors and risk of peptic ulcer disease for patients with $H$. pylori infection

\begin{tabular}{|lccc|}
\hline Factor & $\boldsymbol{P}$ value & Odds ratio & $\mathbf{9 5} \% \mathbf{C I}$ \\
\hline cagT & 0.0001 & 27.329 & $4.535-164.687$ \\
Male gender & 0.0001 & 9.731 & $2.711-34.927$ \\
cagM & 0.0001 & 8.081 & $2.985-21.878$ \\
LEC & 0.003 & 4.366 & $1.676-11.375$ \\
cagA3 & 0.005 & 4.204 & $1.546-11.434$ \\
\hline
\end{tabular}

Africans. Nevertheless, this peculiarity was not a geographical trait, but rather an indication of a fourfold risk of peptic ulcer disease development (Table 3).

The right end of the cagA gene (GenBank accession no. AF001357) encompasses the C-terminal CagA variableregion EPIYA tyrosine phosphorylation motifs (Covacci et al., 1993; Stein et al., 2002; Zhang et al., 2005), which, by tyrosine phosphorylation (Selbach et al., 2002), promote a growth factor-like response with intense cytoskeletal rearrangements, cell elongation effects and increased cellular motility (Stein et al., 2002; Higashi et al., 2005). The frequent deletion of $c a g A 3$ in $H$. pylori isolates from the controls would render these strains less pathogenic. Nevertheless, as this region shows variability, sequence divergence at the primer annealing site could cause a negative PCR result. Thus we shall further analyse the Cterminal cagA variable region by nucleotide sequencing of Brazilian $H$. pylori isolates and analyse the number of EPIYA tyrosine phosphorylation motifs.

Although the region of the cagA gene close to the promoter was frequently found in isolates from both peptic ulcers and controls, Apcag showed a significant difference between isolates from peptic ulcers $(98 \%)$ and from controls $(63.1 \%)$, as shown in Table 2. Similar results were observed in Japanese $H$. pylori isolates (Ikenoue et al., 2001) that lacked the CagA protein in spite of being cagA-positive (Maeda et al., 1999). This contrasts with a report by Kauser et al. (2004), which showed that the cagA promoter was rearranged more frequently in isolates linked to severe pathology than in isolates responsible for a more benign outcome worldwide.
Table 4. Distribution of patients according to gender

\begin{tabular}{|lccc|}
\hline Gender & $\begin{array}{c}\text { No. of peptic } \\
\text { ulcer patients (\%) }\end{array}$ & $\begin{array}{c}\text { No. of } \\
\text { controls (\%) }\end{array}$ & Total no. (\%) \\
\hline Female & $92(61.3)$ & $61(93.8)$ & $153(71.2)$ \\
Male & $58(38.7)$ & $4(6.2)$ & $62(28.8)$ \\
Total & 150 & 65 & 215 \\
& & & \\
${ }^{*} P<0.001$. & & & \\
\end{tabular}

Most of the peptic ulcer disease isolates retained cagT (98\%), cagE (96\%) and cagM (78\%) $(P<0.01$; Table 2). In Japan (Ikenoue et al., 2001), strains with partial or totally deleted cagPAI, which lacked both cagE and cagT, were found more frequently in more patients with chronic gastritis only than in patients with peptic ulcer disease or gastric cancer. In England (Kauser et al., 2005), the majority of ulcer disease strains retained the $c a g T$ and $c a g E$ genes. In fact, $c a g T$, which was positive in $58.5 \%$ of the isolates from the controls, was associated with a 27 -fold risk and cagM with an 8 -fold risk of developing peptic ulcer disease (Table 3). CagT is found at the base of the outgrowing pilus of the type IV secretion system supposed to be responsible for binding to a cellular receptor to induce IL-8 secretion and for ejecting CagA (Rohde et al., 2003). CagE and CagM are absolutely necessary for transcription factor NF- $\kappa \mathrm{B}$ activation, which mediates IL-8 secretion (Glocker et al., 1998).

The LEC was positive in only $58 \%$ of the peptic ulcer $H$. pylori isolates and in $32.3 \%$ of the controls $(P<0.01$; Table 2). Interestingly, the LEC presented a fourfold risk similar to the right end terminus of cagA (Table 3). In South African $H$. pylori isolates, the entire cag II region, including the LEC, was undetectable in $23 \%$ of gastritis-only isolates but in only $8 \%$ of peptic ulceration isolates (Kidd et al., 2001). The LEC (Hp0520/ORF6; Covacci \& Rappuoli, 2000) was not necessary for either translocation of CagA or IL-8 induction (Fischer et al., 2001); however, it might be involved in the pathogenesis of peptic ulceration. Conversely, the LEC is rearranged more frequently in isolates linked to severe pathology worldwide (Kauser et al., 2004).

Table 5. Histology of the antrum collected from patients with peptic ulcers and from controls

\begin{tabular}{|c|c|c|c|}
\hline Histology $y^{\star}$ & No. of peptic ulcer patients (\%) & No. of controls (\%) & Total no. $(\%)$ \\
\hline Normal & - & $5(7.7)$ & $5(2.3)$ \\
\hline Mild & $15(10.1)$ & $25(38.5)$ & $40(18.8)$ \\
\hline Moderate & $119(80.4)$ & $34(52.3)$ & $153(71.8)$ \\
\hline Marked & $13(8.8)$ & $1(1.5)$ & $14(6.6)$ \\
\hline Atrophic & $1(0.7)$ & - & $1(0.5)$ \\
\hline Total & $148^{\star}$ & 65 & 213 \\
\hline
\end{tabular}

${ }^{\star}$ In two patients of the peptic ulcer group, biopsies were not taken for histology before $H$. pylori eradication. $P<0.001$. 
Table 6. Relationship between the positivity of cagPAl genes or segments and histological findings (intensity of gastritis) of the antrum from peptic ulcer patients and controls

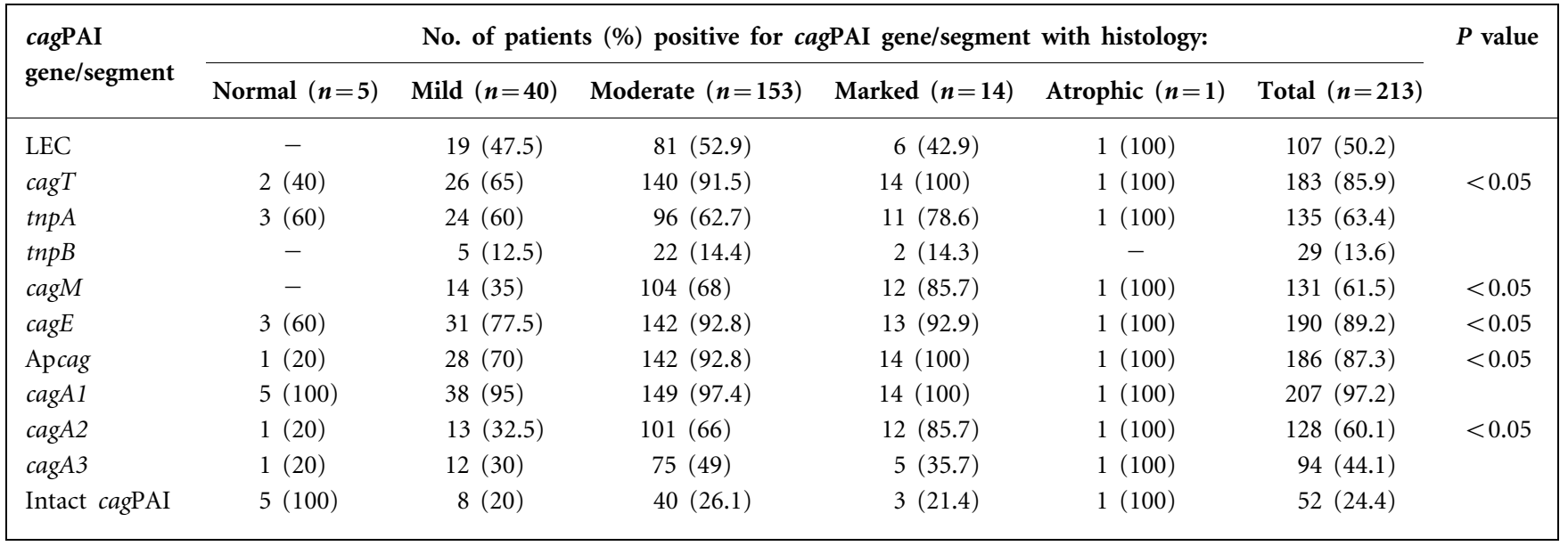

The IS605 insertion sequence $(\operatorname{tnp} A+\operatorname{tn} p B)$ was intact in 19 of the $215(8.8 \%) H$. pylori isolates. The tnpA gene was found more frequently in $\mathrm{H}$. pylori isolates from peptic ulcer patients $(70 \%)$ than in the isolates from the controls $(49.2 \%)(P<0.01)$. The $\operatorname{tn} p B$ gene was usually negative in both groups $(P=0.129)$. On the basis of amino acid sequence similarities, $\operatorname{tn} p A$ and $\operatorname{tn} p B$ could encode transposases and could mediate deletions within the cag I region (Censini et al., 1996). In contrast, peptic ulcer isolates, which were usually $\operatorname{tn} p A$-positive, had cagPAI genes that were more intact than the controls. Other reports (Akopyants et al., 1998; Jenks et al., 1998) have detected partial deletions of tnpA and $\operatorname{tnpB}$ in the majority of $H$. pylori strains; therefore, the cagPAI is generally present as a single block of genes.

The distribution of patients according to gender (Table 4) showed a preponderance of women in both groups. However, women with $H$. pylori infection more often $(93.8 \%)$ had normal endoscopy compared with men $(6.2 \%)(P<0.001)$. Analysis of the peptic ulcer group alone suggested that, unexpectedly, there was a female predominance; however, the control group analysis demonstrated that although the ratio of females to males in the peptic ulcer group was $1.6: 1$, women more commonly had non-ulcer dyspepsia when colonized by $H$. pylori. The risk of male gender for development of peptic ulcers was 9.7-fold; actually, the incidence of peptic ulcer formation was usually higher in men (Dong et al., 2004). Gender differences have been observed in rats with chemically induced gastritis or gastric ulcers; females had a significantly faster ulcer-healing rate due to more proliferating cells and higher $\mathrm{PGE}_{2}$ levels (Liu et al., 2001).

\section{cagPAl genes and histological findings}

DNA for $H$. pylori analysis was extracted from the antrum where the intensity of gastritis was higher; consequently, the histological findings presented in Table 5 were from the antrum and showed that peptic ulcer patients had a more-intense gastritis than the controls $(P<0.001)$. The intensity of gastritis of both groups together was associated with the presence of cagT, Apcag, cagE, cagM and cagA2 ( $P$ $<0.05$ ) (Table 6). The right end termini of cagA (cagA3) and the LEC, although associated with a fourfold risk of peptic ulcer development, had no significant association with intensity of gastritis. Interestingly, $\operatorname{cag} T$ (Rohde et al., 2003), cagE, cagM (Glocker et al., 1998) and cagA (Stein et al., 2002; Higashi et al., 2005) are the genes involved in $H$. pylori induction of gastric epithelial morphological alterations and inflammation.

We conclude that $\operatorname{cagPAI}$ ( $\operatorname{cag} T$, $\operatorname{cag} M$ and $\operatorname{cagA}$ ) genotyping may be useful in clinical practice to indicate dyspeptic nonulcer patients for $H$. pylori eradication in a country with a high prevalence of $H$. pylori infection in the normal population.

\section{ACKNOWLEDGEMENTS}

We thank Jaime Natan Eisig, Tomas Navarro Rodrigues and Fernando Marcuz Silva for providing and caring for the peptic ulcer patients studied. This study was partially supported by CAPES (Coordenação de aperfeiçoamento de pessoal de nível superior).

\section{REFERENCES}

Akopyants, N. S., Clifton, S. W., Kersulyte, D., Crabtree, J. E., Youree, B. E., Reece, C. A., Bukanov, N. O., Drazek, E. S., Roe, B. A. \& Berg, D. E. (1998). Analyses of the cag pathogenicity island of Helicobacter pylori. Mol Microbiol 28, 37-53.

Audibert, C., Burucoa, C., Janvier, B. \& Fauchère, J. L. (2001). Implication of the structure of the Helicobacter pylori cag pathogenicity island in induction of interleukin-8 secretion. Infect Immun 69, 1625-1629.

Backert, S., Schwarz, T., Miehlke, S., Kirsch, C., Sommer, C., Kwok, T., Gerhard, M., Goebel, U. B., Lehn, N. \& other authors (2004). Functional analysis of the cag pathogenicity island in Helicobacter pylori isolates from patients with gastritis, peptic ulcer and gastric cancer. Infect Immun 72, 1043-1056. 
Censini, S., Lange, C., Xiang, Z., Crabtree, J. E., Ghiara, P., Borodovsky, M., Rappuoli, R. \& Covacci, A. (1996). cag, a pathogenicity island of Helicobacter pylori, encodes type I-specific and disease-associated virulence factors. Proc Natl Acad Sci U S A 93, 14648-14653.

Covacci, A. \& Rappuoli, R. (2000). Tyrosine-phosphorylated bacterial proteins: Trojan horses for the host cell. J Exp Med 191, 587-592.

Covacci, A., Censini, S., Bugnoli, M., Petracca, R., Burroni, D., Macchia, G., Massone, A., Papini, E., Xiang, Z. \& other authors (1993). Molecular characterization of the $128-\mathrm{kDa}$ immunodominant antigen of Helicobacter pylori associated with cytotoxicity and duodenal ulcer. Proc Natl Acad Sci U S A 90, 5791-5795.

Dixon, M. F., Genta, R. M., Yardley, J. H. \& Correa, P. (1996). Classification and grading of gastritis. The updated Sydney system. International Workshop on the Histopathology of Gastritis, Houston 1994. Am J Surg Pathol 20, 1161-1181.

Dong, W.-G., Cheng, C.-S., Liu, S.-P. \& Yu, J.-P. (2004). Epidemiology of peptic ulcer disease in Wuhan area of China from 1997 to 2002. World J Gastroenterol 10, 3377-3379.

Fischer, W., Püls, J., Buhrdorf, R., Gebert, B., Odenbreit, S. \& Haas, R. (2001). Systematic mutagenesis of the Helicobacter pylori cag pathogenicity island: essential genes for CagA translocation in host cells and induction of interleukin-8. Mol Microbiol 42, 1337-1348.

Fujioka, N., Fahey, M. T., Hamada, G. S., Nishimoto, I. N., Kowalski, L. P., Iriya, K., Rodrigues, J. J., Tajiri, H. \& Tsugane, S. (2001). Serological immunoglobulin G antibody titers to Helicobacter pylori in Japanese Brazilian and non-Japanese Brazilian gastric cancer patients and controls in Sao Paulo. Jpn J Cancer Res 92, 829-835.

Glocker, E., Lange, C., Covacci, A., Bereswill, S., Kist, M. \& Pahl, H. L. (1998). Proteins encoded by the cag pathogenicity island of Helicobacter pylori are required for NF- $\kappa \mathrm{B}$ activation. Infect Immun 66, 2346-2348.

Hammar, M., Tyszkiewicz, T., Wadström, T. \& O'Toole, P. W. (1992). Rapid detection of Helicobacter pylori in gastric biopsy material by polymerase chain reaction. J Clin Microbiol 30, 54-58.

Higashi, H., Yokoyama, K., Fujii, Y., Ren, S., Yuasa, H., Saadat, I., Murata-Kamiya, N., Azuma, T. \& Hatakeyama, M. (2005). EPIYA motif is a membrane-targeting signal of Helicobacter pylori virulence factor CagA in mammalian cells. J Biol Chem 280, 23130-23137.

Hsu, P.-I., Hwang, I., Cittelly, D., Lai, K.-H., El-Zimaity, H. M., Gutierrez, O., Kim, J. G., Osato, M. S., Graham, D. Y. \& Yamaoka, Y. (2002). Clinical presentation in relation to diversity within the Helicobacter pylori cag pathogenicity island. Am J Gastroenterol 97, 2231-2238

Ikenoue, T., Maeda, S., Ogura, K., Akanuma, M., Mitsuno, Y., Imai, Y., Yoshida, H., Shiratori, Y. \& Omata, M. (2001). Determination of Helicobacter pylori virulence by simple gene analysis of the cag pathogenicity island. Clin Diagn Lab Immunol 8, 181-186.

Jenks, P. J., Mégraud, F. \& Labigne, A. (1998). Clinical outcome after infection with Helicobacter pylori does not appear to be reliably predicted by the presence of the genes of the cag pathogenicity island. Gut 43, 752-758.

Kauser, F., Khan, A. A., Hussain, M. A., Carroll, I. M., Ahmad, N., Tiwari, S., Shouche, Y., Das, B., Alam, M. \& other authors (2004). The cag pathogenicity island of Helicobacter pylori is disrupted in the majority of patient isolates from different human populations. J Clin Microbiol 42, 5302-5308.

Kauser, F., Hussain, M. A., Ahmed, I., Srinivas, S., Devi, S. M., Majeed, A. A., Rao, K. R., Khan, A. A., Sechi, L. A. \& Ahmed, N. (2005). Comparative genomics of Helicobacter pylori isolates recovered from ulcer disease patients in England. BMC Microbiol 5, 32.
Kidd, M., Lastovica, A. J., Atherton, J. C. \& Louw, J. A. (2001). Conservation of the cag pathogenicity island is associated with vacA alleles and gastroduodenal disease in South African Helicobacter pylori isolates. Gut 49, 11-17.

Liu, E. S., Wong, B. C. \& Cho, C. H. (2001). Influence of gender difference and gastritis on gastric ulcer formation in rats. J Gastroenterol Hepatol 16, 740-747.

Maeda, S., Yoshida, H., Ikenoue, T., Ogura, K., Kanai, F., Kato, N., Shiratori, Y. \& Omata, M. (1999). Structure of cag pathogenicity island in Japanese Helicobacter pylori isolates. Gut 44, 336-341.

Maeda, S., Akanuma, M., Mitsuno, Y., Hirata, Y., Ogura, K., Yoshida, H., Shiratori, Y. \& Omata, M. (2001). Distinct mechanism of Helicobacter pylori-mediated NF-kappa B activation between gastric cancer cells and monocytic cells. J Biol Chem 276, 44856-44864.

Mattar, R., dos Santos, A. F., Eisig, J. N., Rodrigues, T. N., Silva, F. M., Lupinacci, R. M., Iriya, K. \& Carrilho, F. J. (2005). No correlation of babA2 with vacA and cagA genotypes of Helicobacter pylori and grading of gastritis from peptic ulcer disease patients in Brazil. Helicobacter 10, 601-608.

Nilsson, C., Sillén, A., Eriksson, L., Strand, M.-L., Enroth, H., Normark, S., Falk, P. \& Engstrand, L. (2003). Correlation between cag pathogenicity island composition and Helicobacter pyloriassociated gastroduodenal disease. Infect Immun 71, 6573-6581.

Owen, R. J., Sharp, S. I., Chisholm, S. A. \& Rijpkema, S. (2003). Identification of cagA tyrosine phosphorylation DNA motifs in Helicobacter pylori isolates from peptic ulcer patients by novel PCRrestriction fragment length polymorphism and real-time fluorescence PCR assays. J Clin Microbiol 41, 3112-3118.

Peek, R. M., Jr (2005). Pathogenesis of Helicobacter pylori infection. Springer Semin Immunopathol 27, 197-215.

Rohde, M., Püls, J., Buhrdorf, R., Fischer, W. \& Haas, R. (2003). A novel sheathed surface organelle of the Helicobacter pylori cag type IV secretion system. Mol Microbiol 49, 219-234.

Rudi, J., Kolb, C., Maiwald, M., Kuck, D., Sieg, A., Galle, P. R. \& Stremmel, W. (1998). Diversity of Helicobacter pylori vacA and cagA genes and relationship to VacA and CagA protein expression, cytotoxin production, and associated diseases. J Clin Microbiol 36, 944-948.

Segal, E. D., Lange, C., Covacci, A., Tompkins, L. S. \& Falkow, S. (1997). Induction of host signal transduction pathways by Helicobacter pylori. Proc Natl Acad Sci U S A 94, 7595-7599.

Segal, E. D., Cha, J., Lo, J., Falkow, S. \& Tompkins, L. S. (1999). Altered states: involvement of phosphorylated CagA in the induction of host cellular growth changes by Helicobacter pylori. Proc Natl Acad Sci U S A 96, 14559-14564.

Selbach, M., Moese, S., Hauck, C. R., Meyer, T. F. \& Backert, S. (2002). Src is the kinase of the Helicobacter pylori CagA protein in vitro and in vivo. J Biol Chem 277, 6775-6778.

Stein, M., Bagnoli, F., Halenbeck, R., Rappuoli, R., Fantl, W. J. \& Covacci, A. (2002). C-Src/Lyn kinases activate Helicobacter pylori CagA through tyrosine phosphorylation of the EPIYA motifs. Mol Microbiol 43, 971-980.

Tummuru, M. K. R., Sharma, S. A. \& Blaser, M. J. (1995). Helicobacter pylori picB, a homologue of the Bordetella pertussis toxin secretion protein, is required for induction of IL- 8 in gastric epithelial cells. Mol Microbiol 18, 867-876.

Zhang, Y., Argent, R. H., Letley, D. P., Thomas, R. J. \& Atherton, J. C. (2005). Tyrosine phosphorylation of CagA from Chinese Helicobacter pylori isolates in AGS gastric epithelial cells. J Clin Microbiol 43, 786-790. 